\title{
The impact of Intellectual Capital measurement on the financial markets: a meta-analysis approach
}

\author{
Stefania Veltri ${ }^{39}$
}

The main aim of the article is to offer a systematic review of the literature on the relation between Intellectual Capital (IC) and Firm Performance (FP) through the statistical technique of meta-analysis (MA). MA synthesizes the quantitative results of different empirical studies on the relationship between explicative, independent variables (IC in our case) and dependent variables (FP) in a common metric called the effect size (Rosenthal, 1984, Hedges and Olkin, 1985, Hunter and Schmidt, 2004/1990). Meta-analysis is scarcely used in business sciences, even if applications in these research areas have increased in the last few years. The originality of the article consists in applying a relatively new technique for business sciences and particularly new for the IC literature. The research of a correlation between IC and FP has always been considered relevant for both a firm's managers and Scholars (Ittner, 2008; Kamiyama et al., 2004), but has encountered many drawbacks, not least the difficulties in measuring IC. Researches on a correlation between IC and FP received a great boost after the publication of the VAIC ${ }^{T M}$ method by Ante Pulic, $(1998,2000,2204)$ which allows the IC performance to be calculated by starting from accounting data. The article, despite the limits deriving from the effectiveness of the measures of the two variables and from a lack of reliability in the measurement of the studies included in the $M A$, tries to summarize, from a statistical point of view, for the first time in the IC literature, the researches existing on such a connection and, above all, to search for the variables responsible for the heterogeneity between studies (moderators). On the whole, there are two ways to conceptualize MA: fixed-effects and random-effects MA (Hedges and Vevea, 1998; Hunter and Schmidt, 2004/1990). The fixed-effect methods assumes that all studies in an MA comes from a population with a fixed-average effect size, whilst random-effect methods assume that average effect size in the population vary from study to study. I chose to utilize a random-effects method, in particular the Hedges and colleagues' method (Hedges and Olkin, 1985, Hedges and Vevea, 1998), since the data collected for the MA are real-world data, likely to have variable-population parameters and because the random-effects method allows inferences that generalize beyond the studies included in MA (Field, 2009). The moderator analysis has been carried out by using a multi-level regression model, due to the hierarchical nature of our data (multiple FP measures in the same study). With respect to the traditional meta-analytic techniques, multilevel modelling structure accounts for dependencies in the data whilst also allowing each study to contribute different effect sizes (Hox, 2002; Van Den Noortgate and Onghena, 2003; Goldstein et al., 2000). Despite to its potential efficacy (Hofmann and Gavin, 1998), few published MA utilized this method, for a distinct lack of prescriptive instructions on how to conduct a MA using multilevel modelling (O'Mara et al., 2005). The main MA result is a positive true effect size of the correlation between IC and firm's performance, whilst, from the moderator analysis, it emerges that the different economic context is the main responsible for the between-study variance, together with the industry and the FP measures $^{40}$.

$J E L: G 32$

Key words: intellectual capital, intangibles, VAIC ${ }^{T M}$, performance, meta-analysis

\footnotetext{
${ }^{39}$ Correspopndecnce address: Stefania Veltri, Reseaarcher in Business Economics, Department of Business Sciences, University of Calabria, 87036 Campus of Arcavacata (CS), Calabria, Italy. Tel: +39-984-492126. E-mail address: stefania.veltri@unical.it

${ }^{40}$ The article is based on a paper submitted to the $5^{\text {th }}$ Workshop on Visualising, Measuring, and Managing Intangibles \& Intellectual Capital, Dresden, Germany, October 8-9, 2009
}

Выпуск \#3(11), 2009

(C) Электронный журнал Корпоративные Финансы, 2009 


\section{Introduction}

Intellectual capital, definable as the dynamic system of knowledge related resources and activities, has become the primary driver of the firm's value creation (Lev and Zambon, 2003). This statement has its confirmation in a series of empirical evidence related to researches which have revealed the estimated contribution of intangibles to the market value of the firms (Lev, 2001; Kaplan and Norton, 2004) ${ }^{41}$.

In the IC literature, there has always been an attempt to demonstrate the existence of a relation between the IC and the FP, proxy of the firm's value, although the research of such a connection has again become critical in recent studies on IC: the number of empirical researches has increased in the last few years with the aim of testing the association between IC and FP through econometric techniques, most of all linked to the utilization of Ante Pulic's VAIC ${ }^{\mathrm{TM}}$ (1998, $2000,2004)$, which made it easier to measure intangibles, since it measures the firm's intellectual performance by starting from accounting data.

The empirical studies produced conflicting results, owing to the specificities included in the studies with relation i. e. to the firms' dimension, to the economic context, to the methodology utilized.

A methodology which allows single empirical studies to avoid being misleading is metaanalysis. This is a quantitative technique of integrative review in which statistical procedures are used to standardize the results of single studies, by highlighting a more objective and general final result. Meta-analysis is scarcely used in business sciences (Pomeroy and Thornton, 2008), even if applications in these research areas have increased in the last few years, but it could be extremely useful to synthetize the empirical studies on the relation between IC and FP.

The main aim of the article is to offer a systematic review of the literature on the relation between IC and FP through the statistical technique of meta-analysis. The originality of the article consists in applying a relatively new technique for business sciences and particularly new for the IC literature (Serenko and Bontis, 2004).

\subsection{Organization of the Study}

Section 2 outlines the theoretical basis of the research, by presenting the variables whose empirical studies tested the association, intellectual capital (IC) and firm performance (FP) and the theory underlining the hypothesis of a direct relationship of IC and FP. Section 3 presents the main features, advantages and limits of the meta-analysis (MA) technique, and summarizes the MA on the association between IC and FP (main results and the moderator analysis), with mathematical details of the exercise relegated to an appendix. Section 4 presents discussions and offers suggestions for future research.

\section{Description of Variables of the Meta-analysis}

\subsection{A Working Definition of the Intellectual Capital}

There is still no universally accepted definition of IC (Zambon, 2003). It is a really complex object of study, still being defined and constantly evolving. IC's main features are the dynamicity and firm-specificity, that is to say the elements which compose the IC change constantly with time and vary in relation to the firm size, industry etc. The notion of IC is also a transversal one: Scholars who focused their interest on intangibles deal with the IC theme in relation to those interests, focusing from time to time on different aspects, functional to their analysis. IC literature

\footnotetext{
${ }^{41}$ In the article the term intangibles and intellectual capital will be used as synonymous.
} 
is full of IC definitions (for a comparison, see Hunter, Webster and Wyatt, 2005; Kaufmann and Scheineder, 2004; Tan et al., 2008b).

Although IC definitions are different, all of them include the notion of knowledge and link the intangibles with the firm's value creation ${ }^{42}$. However, researchers and IC practitioners need a working definition of IC. From the second half of the nineties, numerous Scholars (Bontis, 1996; Edvinnson and Malone, 1997; Stewart, 1997; Sveiby, 1997) started to present schemes able to help a conceptualization of IC and to present the IC notion in a form usable for research. These schemes, with slight differences, tend to converge greatly: the different authors, far from considering the IC a unidimensional construct, agree with the consideration that IC can be found on different levels in the firm; for this reason it does not have to be constrained to the knowledge held by individuals, but also has to include knowledge stored within organizational databases, business processes, systems and relationships.

A scheme that has greatly influenced other researchers is that of Edvinsson and Malone (1997); according to them IC is composed of two main components, human capital (i.e. the knowledge, skills, competencies and experience of employees) and structural capital (i.e. the embodiment, empowerment and supportive infrastructure of human capital), in turn divided into organizational capital (i.e. the systems tools and operating philosophy that speed the flow of knowledge through the organization) and customer capital (i.e. relationships a company has with its customers). Stewart (1997), in a similar way, defines the IC as composed of human capital, structural capital (which includes the organizational one) and customer capital, placed on an equal footing with the other two. Bontis (1996) introduces the notion of relational capital as an extended version of customer capital, which includes the value of all a firm's external relationships. The tripartition of IC into Human Capital (HC), Organizational Capital (OC) and Relational Capital (RC) has also been validated even by the main organizations (IFAC, 1998; OECD, 1999) and by the projects carried out on a supranational level (Meritum, 2001, HLEG, 2003).

\subsection{Intellectual Capital Measurement Methods}

There is no universally accepted IC measurement method. Sveiby (2001a), on the basis of the prior works of Luthy (1998) and Williams (2000), identifies four categories, in relation to the different IC measurement purposes. To the four categories originally identified, we prefer to single out a new one, the Value Added Intellectual Coefficient (VAIC ${ }^{\text {TM}}$ ) methodology, since this method does not quite fit any category (Sveiby, 2001a; Chan, 2009).

There are therefore five methods identified:

a) Direct IC measurement methods, which estimate the monetary value of what a company may consider as individual components of its IC, identified by audit questionnaires. The IC measures can take the form of a dollar value or be aggregated as coefficients (DIC);

b) Market capitalization methods, which calculate IC as the difference between a company's market value and its net asset value (MCM);

c) Return on Assets methods, which calculates IC as a ratio between average annual earnings from intangibles (derived by multiplying the difference between the ROA of a company - the ROA of the industry for the company's average tangible assets) and the company's average cost of capital or an interest rate (ROA);

d) Scorecard methods, which measure IC by identifying its components and expressing them through IC indicators, above all non-monetary, assembled in a company's scorecard (SC);

e) VAIC ${ }^{\text {TM }}$ method, based on an equation which measures how much and how efficiently intellectual capital and capital employed create a company's value.

\footnotetext{
${ }^{42}$ Intangible assets are those that have no physical existence but are still of value to the company" Edvinsson e Malone, 1997, p.22; "IC is intellectual material - knowledge, information, intellectual property, experience-that can be put in use to create value", Stewart, 1997, p. XI,; "IC is knowledge that can be converted into profit", Sullivan, 2000, p.228; "An intangible asset is a claim to future benefit that does not have a physical or financial (a stock or bond) embodiment", Lev, 2001.
} 
A detailed description of the IC measurement methods is something that goes beyond the scope of the article (for a comparison, see Sveiby, 2001a; Zambon, 2003). The VAIC ${ }^{\mathrm{TM}}$ method (Pulic, 1998, 2000, 2004) should be better explained because, since its diffusion as a measure of IC in correlation to FP, it constitues the object of the first MA. formula ${ }^{43}$ :

According to $\mathrm{VAIC}^{\mathrm{TM}}$, corporate intellectual ability can be determined by the following

$$
\mathrm{VAIC}^{\mathrm{TM}}=\mathrm{CEE}+\mathrm{ICE}
$$

The indexes of $\mathrm{VAIC}^{\mathrm{TM}}$ are described in the following table:

The Value Added Intellectual Coefficient $\left(\mathrm{VAIC}^{\mathrm{TM}}\right.$ )

Table 1

\begin{tabular}{|c|c|c|}
\hline Index name & Symbol & Description \\
\hline $\begin{array}{l}\text { Capital Employed (CE) } \\
\text { Efficiency }\end{array}$ & CEE & $\mathrm{CEE}=\mathrm{VA} / \mathrm{CE}$ \\
\hline $\begin{array}{ll}\text { Intellectual } & \text { Capital } \\
\text { Efficiency } & \end{array}$ & ICE & $\begin{array}{l}\mathrm{ICE}=\mathrm{HCE}+ \\
\mathrm{SCE}\end{array}$ \\
\hline Human Capital Efficiency & $\mathrm{HCE}$ & $\mathrm{HCE}=\mathrm{VA} / \mathrm{HC}$ \\
\hline Structural Capital Efficiency & SCE & $\mathrm{SCE}=\mathrm{SC} / \mathrm{VA}$ \\
\hline
\end{tabular}

The VAICTM's become the most used IC index to use in comparison with FP for the following reasons:

- it measures the IC performance (that is how efficiently a firm uses its intangible resources);

- it allows the impact of IC on a firm's performance to be analyzed, together with other physical production factors which have an undoubted impact on it (Galbreath, 2005);

- it provides an IC measurement system consistent with a Resource-Based View by using a value added approach;

- it can be applied to different levels (macro and micro);

- it makes use of financially oriented, audited and published data, enhancing measurement reliability and improving data availability;

- it produces quantifiable, objective and quantitative measurement without the requirement of any subjective grading and awarding of scores or scales;

- it produces a form of standardized measurement and allows comparison across a divisional, company, industry and national level (Firer and Stainback, 2003);

- it allows to assign an economic value to the components of IC

- it has a track record in deployment and application in IC research of listed companies in many countries (Chan, 2009).

\subsection{Firm Performance: Notion and Measurement Methods}

The measurement of a firm's performance is a complex phenomenon, which after all is related to the achievement of a company's objectives. In the article Neely et al.'s definition (1995) of performance measure as a metric used to quantify the efficiency and/or the effectiveness of an action.

The article focuses on the company's objective monetary measures of efficiency and effectiveness since these are the measures mostly used in the studies included in MA. The efficiency measures are productivity measures, variously calculated, but based in any case on accounting measures; the effectiveness measures, a proxy of the measures of value, can be

\footnotetext{
${ }^{43}$ Pulic (1998) validates the distinction of intellectual capital in human capital (HC) and structural capital (SC), which comprehends the organizational and relational capital. AS proxy of HC, Pulic identifies the amount of salaries palee by company (which do not represent the human capital value, but its potential), while it identifies the SC as the difference between the value added and the $\mathrm{HC}(\mathrm{SC}=\mathrm{VA}-\mathrm{HC})$.
} 
distinguished in profitability measures, based on accounting and/or financial data, market measures, based on market data and mixed measures, a particular case of market measures, which measure the level in which company's market value is exceeding its book value.

Each of these categories has its pros and cons. The accounting measures are easy to apply, available, certified by auditors but are focused on past events (Bourne et al., 2000), are influenced by fiscal politics which can mar the balance sheet, ignore the economic value of intangibles (Amir and Lev, 1997). In spite of this, accounting measures remain an indispensable reference and are widely used in research owing to their high explicative capability. Market measures, which take into consideration the economic risk and the economic value of growth opportunities, are not free of criticism, including the minor certainty of the data, because political and social events can distort the market values. Another new typology of FP measures, the measures of sustainability, have also been used in some studies included in MA. The aim of the measures of sustainability is to measure the company's competitive advantage and its sustainability (Villalonga, 2004).

\subsection{The Relation between Intellectual Capital and Firm Performance}

The question of the determinants of a company's performance is one of the central themes of strategic management studies (Galbreath and Galvin, 2008). Over the last two decades this theme has undergone a major shift in focus, from industry-specific to firm-specific factors (Hoopes et al., 2003).

Thus, two competing theories dominate the strategic management field today. The former theory, developed within the industrial economy paradigm, hypothizes that performance variations are due to structural differences in the industry to which the firm belongs, and it is best represented by Porter's (1980) five forces model.

The newest theory identifies the performance drivers with firm-specific factors and it is best represented by the Resource-Based View (RBV): a term coined by Wernerfelt in 1984. The firm is seen as an aggregate of mutually interdependent tangible and intangibile resources ${ }^{44}$. Only valuable, rare, imperfectly imitable and substitutable resources are able to generate sustainable competitive advantages, since they are at the heart of differences in performance (Barney, 1991, Peteraf, 1993; Ahmit and Schoemaker, 1993; Galbreath, 2005).

Intangible resources received a great attention from scholars (Amit and Schoemaker, 1993) since, owing to their peculiarities such as high barriers to competitive duplication (Hall 1992), scalability, increasing scale returns, and the net effect (Lev, 2001), with respect to the conditions prescribed by the RBV to the resources able to generate a sustainable competitive advantage. A recent research of Galbreath and Galvin (2008) compares the effects of firm-specific (resources) and industry-specific factors on the performance variations, proving that, as hypothized by scholars of RBV, unlike tangible resources, only intangible assets and capabilities are able to explain the company's performance variations.

With time, the Resource-Based Theory (Acedo et al., 2006) has been integrated with the competence-based view (CBV), according to which, in the achievement of a competitive advantage, a leading role has to be attributed to capabilities of organizing and managing these resources (Prahalad and Hamel, 1990; Teece et al., 1997), by the application of RBV to the relations between organizations (Dyer, 1996) and by the knowledge-based view - KBV (Nonaka and Tacheuchi, 1995; Grant, 1996), according to which strategically relevant knowledge was seen as a primary driver of the competitive advantage (Grant 1996, Conner and Prahalad, 2002; Sveiby, 2001b). The KBV grows within the context of a knowledge economy, the opposite of an industrial economy based on mass production (Zingales, 2000). In this context, competitive success requires a critical capability to develop, manage, measure and control the knowledge flow (Rubino, 2004,

\footnotetext{
${ }^{44}$ According to a scheme validated in theory (Galbreath, 2005), a firm's resources can be divided into tangible (factors which contain physical or financial value, included in the balance sheet) and intangible ones (factors not financial or physical, rarely included in the balance sheet). Intangible resources can be divided into assets and skills or capabilities (Hall, 1992).
} 
Prism Report, 2003). Since intangibles are based on knowledge, some scholars theorized a more advanced view of KBV, the Intellectual Capital-Based View (Reed et al., 2006), which focuses on stocks and flows of knowledge and on its positive relation with the FP (Carlucci et al. 2004; Tseng and Goo, 2005).

Prism project (2003), theorized within this context, traces out a a new conceptual model of firm, based on competencies, capabilities and knowledge and a new value creation model, based on interconnectiveness of different firm's resources in creating value, with a peculiar focus on intangible resources.

For the reasons expressed above, the hypothesis at the basis of the article is the following:

H1: The intellectual capital, in its three sub-domains, has a direct and positive relationship with the firm's performance.

\section{Meta-analysis of the Relation between Intellectual Capital and the Firm's Performance}

\subsection{Meta-analysis: Object, Aims, Limits, Applications}

Meta-analysis is a statistical technique which synthetizes the quantitative results of different empirical studies on the relationship between explicative, independent variables and dependent variables in a common metric called the effect size (Rosenthal, 1984, Hedges and Olkin, 1985, Hunter and Schmidt, 2004/1990).

MA proved to be useful in many research areas in which single studies led to insignificant or conflicting results, since it allows, and this is its strongest point, exploration of the between study variability (heterogeneity) by identifying the variables that could moderate the effect (Field, 1999).

MA is, actually, the most sophisticated integrative technique, carried out with the same statistical rigour as used in the empirical studies included in it. It offers as an alternative to qualitative techniques such as the narrative reviews, where a reviewer express a judgement, i. e. on the existence or lack of a correlation after having read studies that addressed the question, or the vote counting analysis (Hedges and Olkin, 1980), where a reviewer expresses a judgement on the existence or the lack of correlation by counting the studies codified as positive, negative or insignificant. The main limits of qualitative techniques are the reviewer's subjectivity, the heterogeneity of the studies considered, the lesser usefulness as more information becomes available, the difficulty of arriving at a conclusive result (Boreinstein et al., 2009; Suri, 2000).

MA has several advantages over traditional qualitative review, even though I believe that a good research synthesis should comprehensively include quantitative as well as qualitative findings (Suri, 2000, Rosenthal and Di Matteo, 2001). MA not only shows the direction of the effect, but also quantifies the effect and identifies the moderator variables. It includes all the quantitative empirical studies relevant to the research question, can provide a general conclusive answer to a question, is sufficiently robust to deal with a large number of empirical studies and explicitely states the criteria used to select empirical studies (Hunter \& Schmidt, 2004/1990).

The major risks an MA reviewer runs in doing an MA are: to report the summary effect and ignore the heterogeneity; to mix studies with different characteristics (apples and oranges limit) and/or their quality (garbage in, garbage out limit); to include in the MA only significant findings, which are more likely to be published than insignificant ones, both because researchers do not submit them and reviewers tend to reject manuscripts containing them (file drawer or publication bias); to use the MA method improperly (Bailar, 1997; Hunt, 1997; Sharpe, 1997; Field, 2003; Boreinstein et al., 2009).

By the way, all these limits can be corrected since the MA reviewer can: overcome the apples and oranges and garbage in garbage out limits by coding the differences in moderator variables, variables that interact with the independent variable to produce variation in the study outcomes; include in the MA also unpublished findings to overcome the publication bias; study properties of the different meta-analytic methods (fixed- or random-effects, simple or multilevel) in order to choose the method that best fits the data features. 
With respect to the traditional meta-analytic techniques, multilevel modelling structure accounts for dependencies in the data whilst also allowing each study to contribute different effect sizes (Hox, 2002; Van Den Noortgate and Onghena, 2003; Goldstein et al., 2000). Despite to its potential efficacy (Hofmann and Gavin, 1998), few published MA utilized this method, for a distinct lack of prescriptive instructions on how to conduct a MA using multilevel modelling (O'Mara et al., 2005). Because of the nested nature of our data (multiple FP measures for each article, we use a multi-level approach in the moderator analysis.

The use of MA has grown exponentially in the last two decades, especially in the medical, pharmaceutical, educational and psychological research fields.

By the way, the use of the MA as tool to synthetize quantitative researchs is increasing in economics (Stanley, 2001; Florax et al., 2002), business sciences (Sanchez-Ballesta and GarciaMeca, 2007; Datta et al. 1992; Gooding and Wagner 1985; Orlitzky et al., 2003; La Rocca 2008) and accounting/auditing literature (Derfuss, 2009; Pomeroy and Thornton, 2008; and the studies of Trotman and Wood, 1991; Hay et al., 2006; Kinney and Martin, 1994; Christie, 1990; Ahmed and Courtis, 1999; Brierley, 1999; Dole and Schroeder, 2001; Borkowski, 1996; Fletcher, 1995; Cooper et al., 1985; Greenberg et al., 1994; Thornton, 1994; Zager et al., 2001 in Pomeroy and Thornton, 2008).

\subsection{Meta-analysis of the Relation between Intellectual Capital and Firm Performance: Objectives} and Main Phases

The main objective of the developed meta-analysis is to provide a statistical integration of the studies focused on the relationship between IC and FP. The second level objectives are: 1) to establish a quantitative generalization of the effects of IC on the FP; 2) to determine whether the differences between studies are due to moderator effects, such as the economic context, the measures of FP and IC utilized etc. This is the first MA on such a relation, since until now there are only narrative reviews on the relation between IC and FP (Veltri, 2008; Lev, 2001; Kamiyama et al., 2004).

The phases of the MA have been the following (Field,1999; Rosenthal, 1995; Rosenthal and DiMatteo 2001; La Rocca, 2008; Field, 2009):

a) the definition of the relation object of the research;

b) the literature search;

c) the criteria for including studies and their coding;

d) the description of the studies included in the meta-analysis;

e) the calculation of the effect sizes;

f) the calculation of the mean effect size;

g) the moderator analysis;

h) the synthesis of the meta-analysis main results.

a) The definition of the relation object of the research

The article examines the relation between IC and FP, once again critical after a period in which it was neglected in the IC literature (Petty and Guthrie, 2000). The first article which studied the relation between the three IC subdomains (measured through questionnaires) and FP dated 1998 (Bontis, 1998). The article constitutes a relevant reference point in these kinds of research, but the precise turning point occured when Pulic (1998) presented his index for calculating the efficiency of the IC. One of the problems encountered by researchers who wanted to test the association between IC and FP is, in fact, the difficulty in measuring IC and the VAICTM, even if with its limitations (Chen et al., 2005 underlined its focalization on human capital and its subsequent incompleteness in measuring structural capital), had a propulsive effect on empirical research on the relation between IC and FP, since it is based on accounting data, certified and freely available to researchers, and it is easy to calculate.

Since VAIC TM features make this IC index the most used in empirical research on the IC-FP relation, in the first phase the MA focused on the relation between IC measured by VAIC ${ }^{\text {TM }}$ and 
FP, then, in the second phase, in a sequential and cumulative way (Boreinstein et al., 2009), all the empirical studies which measure the relation between IC, globally measured, and FP, were included in the MA. In the cumulative MA, the methods used in empirical research, apart from VAIC ${ }^{\mathrm{TM}}$, belong to the ROA and MCM methods, which use the monetary metric and measure the global company's IC.

b) The literature search

Once clearly defined the relation object of the MA, a wide-ranging research was carried out in order to collect as large a number of findings as possible on the IC-FP relation. The collection of pertinent articles took place, without defining temporal limits, using the metabib research engine, which, on the web site of the University of Calabria, includes many databases, such as EBSCO (Business Source Premier), Emeroteca Virtuale, ISI web of Knowledge, Jstor etc. The key words put in the databases were the following: "Firm Performance", "Intellectual Capital Performance", "Intellectual Capital", Intangibles", "Value Added Intellectual Coefficient", "VAICTM" "Human Capital" "Structural Capital" "Organizational Capital" "Relational Capital". A parallel literature search was carried out via internet on Google Scholar, which provides a search of scholarly literature across many disciplines and sources, including theses, books, abstracts and articles. The research provides additional references of scientific articles on the object of the MA and also supplies references relative to papers presented to international conferences or dissertation theses.

In order to mitigate the publication bias limit, particularly acute in accounting literature (Pomeroy and Thornton, 2008; Lindsay, 1994), also those unpublished findings have been included in the MA, which can be equally as valuable as the published ones (Lipsey and Wilson, 2001), and, to obtain them, the authors have been successfully contacted via e-mail. With the same aim also conference databases, Social Science Research Network (SSRN) and IEEE explore have been searched ${ }^{45}$. The bibliographical references of the articles and papers retrieved were examined to obtain additional references and representative authors on the subject were also contacted via email, to ask for additional references on the subject. The same kind of literature search was carried out manually, in the scientific economic national and international reviews on accounting, IC and knowledge management reviews of the university library.

c) The criteria for including studies and their coding

Quantitative empirical studies have been included in the MA which complied with the following rules: 1) the FP was the dependent variable; 2) the IC, as an aggregate measure, was the explicative variable; 3) the association between these two variables was tested quantitatively through correlation or regression analysis.

Therefore, studies which did not report sufficient quantitative information to allow to calculate, even if with indirect formulas, the correlation between the two variables were not included in the MA, such as studies that take into consideration the relation between the single components of VAIC ${ }^{\mathrm{TM}}$ and the FP, or the correlation between a single IC component (i.e. trademark, innovation, R\&D expenses) and the FP. For the the same reason, studies on the relation between Human Resources Management Practices and FP have also been excluded. From the literary search 110 empirical studies in English language were collected, codified in an excel sheet and carefully read to verify their suitability to be included in the MA; the reason for their exclusion was also codified. The author, helped by a PHD student, independently coded all the data; the few discrepancies that occurred were resolved through discussions in reference to the coding scheme ${ }^{46}$.

As a consequence of the application of the inclusion criteria, the final sample includes 17 empirical studies, for the VAICTM-FP first meta-analysis, which became 21 (131 relations) for the second, cumulative MA between the IC measured with objective methods and the FP, marked with

\footnotetext{
${ }^{45}$ SSRN, acronym of Social Science Research Network, is a portal dedicated to the promotion and diffusion of scientific results not yet published on reviews, which covers different fields: economic, financial, accounting, managerial, social, juridical. IEEE is a portal which allows to access to high quality technical literature (newspapers and conference proceedings) in the fields of electronic engineering and informatics.

${ }^{46}$ The data has been coded and processed meta-analitically by the author and a trained PHD student, Nicola Patitucci, that the author thanks for his assistance.
} 
an asterisk in the references. The number of studies is considered sufficiently wide (at least 20) to guarantee the reliability of results (Field, 2003b). The large number of relations with respect to the number of studies is due to the consideration that many researchers used multiple measures of IC and FP. There are two general approach to deal with multiple measurement within studies, the single value approach, in which each study in the MA is represented by a single value, and the complete set approach, in which all measurements are included individually in the analysis. The Bijmolt and Pieters' (2001) advice has been followed to avoid meta-analytic procedures representing each study by a single value, because they result in a serious loss of information ${ }^{47}$. Like Brewin et al. (2007), the analyses studies have been allowed to contribute more than one effect size to the analysis, because of the small number of studies selected and of the use of different measures of performances within the study.

d) The description of characteristics of the studies included in the meta-analysis

For each study included in the MA, the following variables have been reported: author(s); year; hypothesis to test; measures of IC; measures of FP, sample and country; quantitative method; control variables; results; type of publication.

The studies included in MA are different both in sign and intensity of the relation identified; the qualitative analysis highlights the main peculiarities which could be at the basis of the differences between studies.

The research embraces a limited period of time, from 2000 to 2009 . The hypothesis to be demonstrated is always to test the correlation between IC (independent variable) and FP (dependent variable), with some differences related to the measurement of the two variables. Table 2 summarizes the main measures of IC extracted from the studies included in MA.

Measures of Intellectual Capital

Table 2

\begin{tabular}{|c|c|}
\hline Value Added Intellectual Coeficient (VAIC ${ }^{\mathrm{TM}}$ ) & $\begin{array}{l}\text { Kujansivu and Lonnqvist, 2007; Vali, 2007; } \\
\text { Pulic, 2000; Saengchan, 2008; Zhang et al., } \\
\text { 2006; Firer and Stainback, 2003; Najibullah, } \\
\text { 2005; Appuhami, 2007; Jin and Wu, 2008; } \\
\text { Jin, 2008a; Jin 2008b; Tan et al., 2008; Shiu, } \\
\text { 2006; Chen et al., 2005; Chan, 2009; } \\
\text { Kamath, } 2008\end{array}$ \\
\hline Intellectual Capital Efficiency (ICE) & $\begin{array}{l}\text { Kujansivu and Lonnqvist, 2007; Richieri et } \\
\text { al., } 2008\end{array}$ \\
\hline $\begin{array}{l}\text { Market-to-book value (MBV) } \\
\text { Difference between market value and book value }\end{array}$ & Iswati and Anshori, 2008 \\
\hline $\begin{array}{l}\text { Market Value Added (MVA) } \\
\text { Ratio between market value and book value }\end{array}$ & Juma and Payne, 2004 \\
\hline $\begin{array}{l}\text { Economic Value Added }\left(\mathrm{EVA}^{\mathrm{TM}}\right) \\
\text { NOPAT- }(\text { WACC } * \text { invested capital }) . \\
\text { NOPAT }=\text { Net Operating Profit After Operating } \\
\text { Taxes; WACC }=\text { Weighted Average Cost of } \\
\text { Capital })\end{array}$ & Juma and Payne, 2004 \\
\hline Tobin's Q & Villalonga, 2004 \\
\hline
\end{tabular}

\footnotetext{
${ }^{47}$ The study of Bijmolt and Pieters (2001) compared alternative procedures, single value approach (each study in metaanalysis is represented by a single value) and complete measurement approach (all measurements are included individually in the analysis) to deal with studies containing multiple measurements through the analysis of synthetic data sets in a Monte Carlo study and an actual marketing meta-analysis. The results show that the performance of metaanalytic procedure that reduce each study to a single value is generally unsatisfactory; they do not perform very well with respect to recovering the true measurement of the effects and the estimated effects of moderator variables deviate substantially from the true values.
} 
Ratio between the firm's market value and the substitution cost of its assets

Calculated Intangible Value (CIV)

The method determines the proportion of return attributable to intangible assets on the basis of excess return on hard assets

Intangible intensity (II)

Intangible expenditures/sales

\section{Capitalized intangibles $(\mathrm{CI})$}

Intangible assets/total assets

Kujansivu and Lonnqvist, 2007; Richieri et al., 2008

As can be noticed, studies with $\mathrm{VAIC}^{\mathrm{TM}}$ as a measure of IC do not associate it with other measures of IC (except for the study of Kujansivu and Lonnqvist, 2007), whilst the studies included in the second step of the MA used more than one measure of IC.

The dependent variable examined in the studies included in MA is Firm Performance. Authors did not take into considerations a monodimensional construct of performance but, in the great majority of studies, use simultaneously ratios of productivity, profitability, market (and mixed) measures. Table 3 summarizes the mean measures of FP extracted from the studies included in the MA.

Table 3

Measures of firm performance

\begin{tabular}{|c|c|}
\hline Profitability & $\begin{array}{l}\text { ROE }=\text { pre-tax income/total shareholder's equity: Richieri et al., 2008; } \\
\text { Najibullah, 2005; Chen et al., 2005; Chan, 2009 }\end{array}$ \\
\hline & $\begin{array}{l}\text { ROI }=\text { net income before extraordinary items/total invested capital: Juma e } \\
\text { Payne, 2004; Kujansivu and Lonnqviust, } 2007\end{array}$ \\
\hline & $\begin{array}{l}\text { ROA }=\text { net income from continuous operations excluding extraordinary } \\
\text { items/total assets: Richieri et al., 2008; Juma and Payne, 2004; Sangchaen, } \\
\text { 2008, Zhang et al., 2006; Najibullah, 2005; Firer and Stainback, 2003; Shiu, } \\
\text { 2006; Chen et al., 2005; Chan, 2009; Kamath, } 2008\end{array}$ \\
\hline & $\mathbf{R O S}=$ operating income/sales: Richieri et al., 2008 \\
\hline & $\begin{array}{l}\text { Cash on hand rate }=\text { number of months that a company has cash available to } \\
\text { operate: Vali, } 2007\end{array}$ \\
\hline & $\begin{array}{l}\text { Growth in revenues }=((\text { sales year } n / \text { sales year } n-1)-1) * 100 \%: \text { Najibullah, } \\
2005 ; \text { Chen et al., } 2005\end{array}$ \\
\hline Market & Investors' capital gain on shares: Appuhami, 2007 \\
\hline & $\begin{array}{l}\text { Earning per share (EPS) = profit to shareholders/weighted average number } \\
\text { of shares: Tan et al., } 2007\end{array}$ \\
\hline & $\begin{array}{l}\text { Annual Stock return }(\mathrm{ASR})=((\text { share price } n+1-\text { share price } n)+ \\
\text { dividend)/share price } n \text { : Tan } \text { et al., } 2007\end{array}$ \\
\hline Mixed & $\begin{array}{l}\text { MVA (o MB)= Pulic, 2000; Vali, 2007; Firer and Stainback, 2003; Shiu, } \\
\text { 2006; Chen et al., 2005; Chan, 2009; Kamath, 2008; Cazavan-Jeny, 2003 }\end{array}$ \\
\hline ability & $\begin{array}{l}\text { Firm-specific profits }=\text { difference between firm's profitability, measured by } \\
\text { ROA and the average profitability of the industry in any given year: } \\
\text { Villalonga, } 2004\end{array}$ \\
\hline & $\begin{array}{l}\text { Firm's sustainable growth ability= based on the Van Horne's model (1988): } \\
\text { Jin e } \mathrm{Wu}, 2008\end{array}$ \\
\hline & $\begin{array}{l}\text { Firm's development ability }=a \text { sum of indices built by the author: Jin, } \\
\text { 2008a; Jin, } 2008 \mathrm{~b}\end{array}$ \\
\hline Produ & Cost to Assets $=$ operating costs/total assets: Sangchaen, 2008 \\
\hline & /number of employees: Kujansivu and Lonnqvist, 2007 \\
\hline
\end{tabular}


Asset Turnover ratio (ATO) = total revenue/total assets: Firer and Stainback, 2003; Shiu, 2006; Chan, 2009; Kamath, 2008

Employee productivity $=$ pre-tax income/number of employees: Najibullah, 2005; Chen et al., 2005

In relation to the sample, the empirical studies show a great variety in the size of sample; by the way, MA takes care of this variable in calculating the true effect size. Some studies recorded observations for only one year (Vali, 2007; Zhang et al., 2006; Firer and Stainback, 2003; Najibullah, 2005; Appuhami, 2007; Shiu, 2006; Cazavan-Jeny, 2003; Iswati and Ashori, 2008); others for more than one year (Kujansivu and Lonnqvist, 2007; Pulic, 2000; Saengchan, 2008; Jin and $\mathrm{Wu}, 2008$; Jin, 2008a; Jin 2008b; Chen et al., 2005; Chan, 2009; Kamath, 2008; Juma and Payne, 2004; Villalonga, 2004; Tan et al., 2008a).

From the analysis of the economic context, it emerges that the many researchers analyze the IC-FP relation in emerging economies, especially Asiatic, probably because in the last few years Asian countries have been growing dynamically and competitively and their economy is mainly based on innovation (Kaplan and Norton, 2004).

Table 4

Studies classified in relation to the economic context

Firms belonging to consolidate economies

Kujiansivu and Lonnqvist, 2007; Vali, 2007; Pulic, 2000; CazavanJeny, 2003; Villalonga, 2004; Juma and Payne, 2004
Firms belonging to emerging economies

Sangchaen, 2008; Zhan et al., 2006; Firer and Stainback, 2003; Najibullah, 2005; Appuhami, 2007; Jin 2008a; Jin $2008 \mathrm{~b}$; Jin and Wu, 2008Shiu, 2006; Chen et al., 2005; Chan 2009; Kamath, 2008; Iswati and Ashori, 2008; Richieri et al., 2008; Tan et al., 2007

In relation to industry, there is a preponderance of empirical studies on firms operating in technological and financial services probably because these industries play a relevant role in emerging economies (Appuhami, 2007); many studies are focused on the banking sector, considered an intellectual intensive one (Sangchaen, 2008).

Table 5.

\section{Studies classified in relation to the industry}

Firms belonging to the technological or financial services' industries
Firms selected randomly or belonging to other industries

Kujansivu and Lonnqvist, 2007; Vali, Kujansivu and Lonnqvist, 2007; Pulic, 2000; Zhang 2007; Sangchaen, 2008; Firer and et al., 2006; Jin and Wu, 2008; Chen et al., 2005; Stainback, 2003; Naibullah, 2005; Chan, 2009; Kamath, 2008; Richieri et al., 2008; Appuhami, 2007; Jin, 2008a; Jin 2008b; Cazavan-Jeny, 2003, Villalonga, 2004; Tan et al., Shiu, 2006; Juma and Payne, 2004; Iswati 2007 and Ashori, 2008

Empirical studies were also examined in relation to the typology of study (published/ unpublished). This variable is useful to test also the quality of study (papers have not fully survived peer-review processes), since few studies measure the reliability of the research (Vali, 2007) and no study has been replicated (Pomeroy and Thorton, 2008). 
Studies classified in relation to the publication type

Studies published as articles on international referred reviews

Villalonga, 2004; Juma and Payne, 2004; Kamath, 2008; Chan, 2009; Shiu, 2006; Chen et al., 2005; Firer and Stainback, 2003; Zhang et al., 2006; Kujansivu and Lonnqvist, 2007

Another variable frequently taken into consideration is the size of the firm. Granted that all firms in the sample are listed firms, size was used as control variable in the studies of Kujansivu and Lonnqvist, 2007; Firer and Stainback, 2003; Jin, 2008a, Jin 2008b, Jin and Wu, 2008; Shiu, 2006; Chan, 2009; Kamath, 2008; Juma and Payne, 2004.

Empirical studies were also compared in relation to their results, showing conflicting results. Pulic (2000), finds a positive relation between VAICTM and MVA, like Chen et al., 2005; Naibullah, 2005. Vali (2007) does not find evidence of a relation between VAIC ${ }^{\text {TM }}$ and MVA, like Kamath (2008) and Cazavan-Jeny (2003), whilst Firer and Stainback (2003) individuate an insignificant relation between VAIC ${ }^{\text {TM }}$ and MVA; Vali (2007) single out a positive relation between VAIC ${ }^{\text {TM }}$ and financial performance, like Kujansivu and Lonnqvist (2007), Sangchaen (2008), Firer and Stainback (2003), Naibullah, (2005), Zhang et al., (2006), Juma and Payne (2004), Richieri et al. (2008). Kujansivu and Lonnqvist (2007) find strong positive correlations between VAIC ${ }^{\text {TM }}$, CIV and ICE with productivity, Sangchaen (2008) and Naijbullah (2005) highlight a positive correlation between VAIC ${ }^{\text {TM }}$ and productivity, while Firer e Stainback (2003) highlight a negative correlation between VAICTM and productivity. The dimension of the effect is obviously different; the next step of MA consists in determining the sizes of the relation object of study expressing them in the same metric in order to determine the mean effect size.

e) The calculation of the effect sizes

An effect size is the measure of the strength of an observed effect. There are various usable metrics (Rosenthal, 1984), but in the MA, coherently with the MA economic literature, the Pearson correlation coefficient $r$ has beden chosen, since it measures the strength of correlation between two continuous variables (Rosenthal and Di Matteo, 2001). Through conversion formulas all the test statistics different from $r$ used to measure the association between IC and FP were related to $\mathrm{r}$. It must be underlined that all studies included in MA hypothesize a linear relation between the two variables, otherwise $r$ will not be an adequate measure of the association (Sanchez-Ballesta and Garcia-Meca, 2007).

f) The calculation of the true effect size

Once the relevant studies are collected and the effect sizes calculated for each study, MA is done in order to estimate the true effect size. On the whole, there are two ways to conceptualize MA: fixed-effects and random-effects MA (Hedges and Vevea, 1998; Hunter and Schmidt, 2004/1990). The fixed-effect methods assumes that all studies in an MA comes from a population with a fixed-average effect size, whilst random-effect methods assume that average effect size in the population vary from study to study. A fixed effect analysis estimates the assumed common effect, whereas a random effect analysis estimates the mean of effect across the studies; in other words a random-effects method returns a less accurate (wider confidence intervals) but more reliable estimate (Higgins and Thompson, 2002).

Coherently with Field (2009) and Boreinstein et al. (2009), the choice of the MA reviewer to use a fixed- or random-effects method has to be taken in advance and depends both on the assumptions that can realistically be made about the population from which the studies are sampled and the type of inferences that the MA reviewer wishes to make from the MA (Hedges and Vevea, 1998). A random-effects method has been chosen to process meta-analitically the data, since the data collected for the MA are real-world data, likely to have variable-population parameters and 
because the random-effects method allows inferences that generalize beyond the studies included in MA (Field, 2009).

The two most-widely used random-effect methods are those by Hunter and Schmidt (2004/1990) and Hedges and colleagues (Hedges and Olkin, 1985, Hedges and Vevea, 1998) (Field, 1999). Both random-effects methods produce accurate estimates of the population effect size (Field, 2005). The Hedge and Vevea's method has been chosen for different reasons: 1) it controls the Type I error rate (i.e. rejecting a null hypothesis when the null is true) better than the Hunter-Schmidt method when 20 or more studies are included;2) it is in general better in achieving 95\% confidence intervals (those of Hunter and Schmidt tend to be narrow); 3 ) it can revert to fixed effects, if it is the case, with little cost, since the random effect version can be calculated as the following step of the fixed effects one (Field, 2005). For mathematical details, see Appendix.

g) The moderator analysis

The aim of the moderator analysis is to look for possible variables that explain variation between effect sizes. There can be various moderator variables, from the characteristics of an individual study to the different modalities in measuring explicative and dependent variables, the different econometric models used, the economic context, the firms' belonging to industry, the sample characteristics, etc. (Stanley and Jarrel, 1989; Derfuss, 2009). Starting from the qualitative analysis carried out, the moderator variables selected, that is, the variables for which is hypothesized a probable moderating effect are the following:

Table 7

The selected moderators

\begin{tabular}{|l|l|}
\hline \multicolumn{1}{|c|}{ Heterogeneity factors } & \multicolumn{1}{c|}{ Description of dummies } \\
\hline Performance measures & $\begin{array}{l}\text { Productivity - profitability - market (and mixed) - } \\
\text { sustainability measures }\end{array}$ \\
\hline Intellectual Capital measures & VAIC $\mathbf{T M}$ - Non VAIC ${ }^{\text {MM }}$ \\
\hline Economic context & Consolidate economies - Emerging economies \\
\hline Industry & Financial and technological services - Others \\
\hline Quality of publication & Articles - Papers and proceedings \\
\hline
\end{tabular}

Given the wide variety and the different results achieved in relation to the different kind of measures used in studies, FP measures were chosen as moderating variables. For the same reasons, the use or otherwise of the VAIC TM methodology as a moderating variable has been tested in the cumulative MA. The economic context, codified as consolidated or emerging economies, is an important reading key of results and could be one the more important moderators able to explain the differences between studies: different maturities of the markets correspond to different economic contexts and a different consciousness of investors on the importance of intellectual capital as the firm's competitive resource.

Another factor interesting to analyze as a moderator is the belonging of firms to industry; the sector variable, that is the separation between the technological and financial services sector and other sectors (in which we included the random samples), has been considered a potential moderator variable, since service industries are considered intellectual intensive and sampled more than others in searching for the correlation IC-FP. A recent research (Galbreath and Galvin, 2008) highlight that in services firms (unlike manifacturing firms) intangible resources are more important than industry structure in explaining performance variation. The last variable chosen as potential moderator is the type of publication, proxy of the different quality of studies. Due to the hierarchical nature of meta-analytical, and also of the data used in the MA (multiple FP measures in the same study), a multilevel metaregression model has been applied. For mathematical details, see Appendix.

h) The synthesis of meta-analysis main results 
MA was carried out on 131 effect sizes on the relation between IC and FP. To visually summarize the distribution of effect sizes included in MA, as advised by Rosenthal (1995), Field (2009) and Brewin et al. (2007), a stem-and-leaf plot of the computed effect sizes has been used

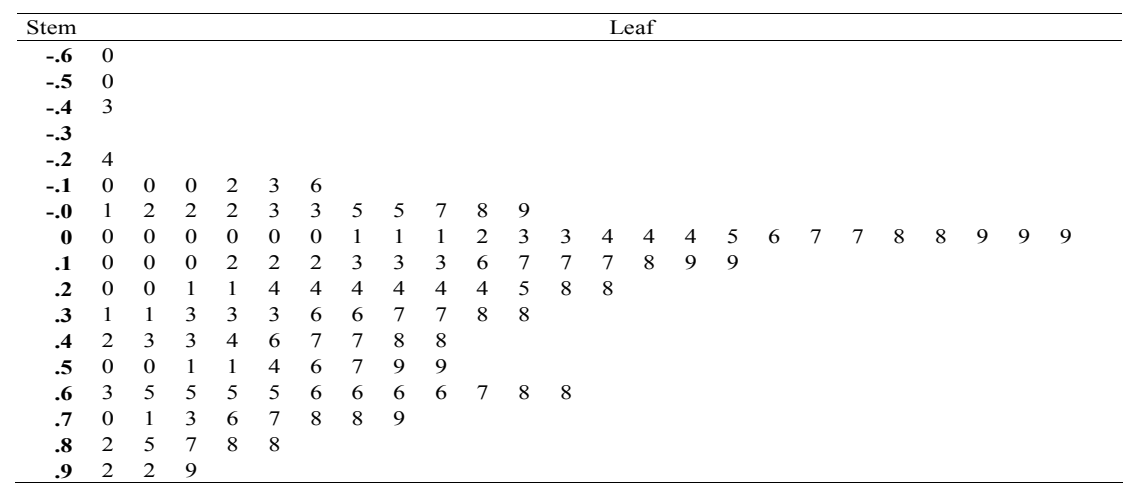

Figure 1. Stem-and-Leaf Plot of All Effect-Sizes (rs)

The mode of the distribution is around 0 , after which a fairly even number of effect sizes cluster around the interval between .1 and .6. Figure 2 shows, through two box-and-whiskers plots, the main data of the central tendency, variability and distribution form of the two meta-analyses.

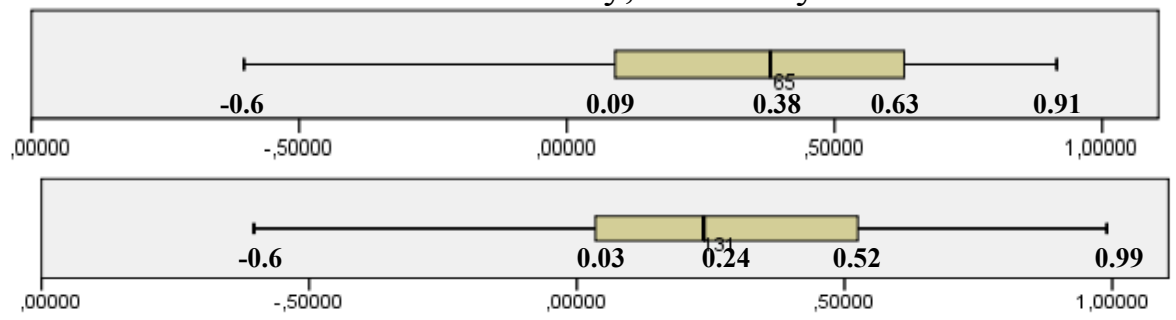

Figure 2. Box-and-Whiskers' plots of the two meta-analyses

Table 8 summarizes the main statistical indicators of the meta-analyses carried out.

Main statistical indicators of random-effects meta-analyses

Table 8

\begin{tabular}{|c|c|c|c|c|c|c|c|c|}
\hline & $\begin{array}{c}\text { Effect } \\
\text { sizes }\end{array}$ & $\bar{r}^{*}$ & $\mathbf{S E}$ & $\mathbf{9 5} \mathbf{C I}$ & $\begin{array}{c}\text { Significance } \\
\text { test (z } \\
\text { score) }\end{array}$ & $\mathbf{N f s}$ & $\mathbf{Q}$ & $\mathbf{I}^{\mathbf{2}}$ \\
\hline VAIC & 65 & 0.37 & 0.03 & $\begin{array}{c}0.29 \text { to } \\
0.43\end{array}$ & $9.26^{*}$ & 2,870 & $14,288^{*}$ & $99.5 \%$ \\
\hline IC & 131 & 0.34 & 0.03 & $\begin{array}{c}0.28 \text { to } \\
0.39\end{array}$ & $10.61^{*}$ & 6,893 & $57,885^{*}$ & $99.7 \%$ \\
\hline
\end{tabular}

$*=p<.001$

The true effect size for both meta-analyses records a positive value, that is, a positive relation of medium intensity between IC and FP, with highly significant associated zs score. The confidence intervals tell us that there is a $95 \%$ probability that the interval estimated includes the true value for the population.

In order to estimate the effect of publication bias, the Rosenthal's (1979) fail-safe $\mathrm{N}$ has been calculated. This is a method for estimating the number of unpublished studies that would be needed to turn a significant population effect size estimate into an insignificant one. The fail-safe $\mathrm{N}$ values show a sufficient resistance to the publication bias, since 2,870 new, unpublished, or unretrieved studies for the MA on VAIC and 6,893 for the cumulative MA would be required to bring the significance of these average effect size to insignificance. 
The $Q$ statistic, the standard test used to estimate the variance between studies, shows heterogeneity $(\mathrm{p}<0.001)^{48}$ as $\mathrm{I}^{2}$ does. $\mathrm{I}^{2}$ is a statistic ratio which shows the proportion of total variation due to the between-study variance, calculated in order to overcome the well-known limit of the Q-test, which is dependent on the number of studies (Higgins and Thomson, 2002; HuedoMedina et al., 2006).

To further explore this result, a moderator analysis has been conducted through a multilevel metaregression analysis. From the analysis the context, the sector and the use of performance's measure (productivity) result as moderator variables (see appendix).

To operate in an economically advanced context (Europe and America) rather than in emerging economies, strengthens the association between IC and FP. Under a theoretical profile, this effect finds its justification in the consideration that a more advanced context registers a greater consciousness of investors. To operate in financial and technological services rather than in other industries strengthens the association between IC and FP. Under a theoretical profile, this effect finds its justification in the consideration that these sectors are intellectual capital intensive ones. In relation to the variable measures of performance, only production reveals to be a moderating factor in both MAs.

\section{Discussions and implications for future research}

The article focusses on a meta-analysis of the relations between intellectual capital and firm performance. The reasons for a meta-analysis on such a relaton resides, besides in the opportunity to highlight a general summarizing result of the different quantitative research, above all in the need to further explore conflicting results of studies. The true effect size shows, not surprisingly, a positive, medium intensity effect, since it is an estimate of different effects sizes from different studies.

Among the possible reasons for this medium intensity positive effect size could be hypothesized many reasons, such as the limited number of studies, owing to the relative novelty of the research object, the consideration that some studies ignore the need to further explore the relation over several years, the consideration that authors hypothesize a linear relationship, whilst a non-linear one could better explicate the relation between the two variables (Huang and Liu, 2005; Kujansivu and Lonnqvist, 2007).

Other reasons could be the consideration that the great majority of studies do not consider that IC could be a predictor of a future FP (Chen, Cheng and Hwang, 2005), the difficulties encountered by authors in building convincing constructs of FP and IC, the great variety of FP measures used; the limits of VAIC ${ }^{\text {TM }}$ tool, strongly focused on human component (Chen et al., 2005).

Many authors highlight the greater explicative power of the model which puts in relation the three VAIC TM's components with the FP, theoretically justified by the consideration that investors give a different value to the three VAIC'M's components (Chen et al., 2005, Vali, 2007; Zhang 2006; Jin, 2008b, Chan, 2009). This led the authors to take into consideration that it could be not a direct, but an indirect relation between the two variables (Galbreath, 2005; Kujansivu and Lonnqvist, 2007), probably mediated by some factors. Among them one of the most accredited factors is human capital (Bontis, 1998). In order to highlight the eventual moderator role of the three VAIC ${ }^{\text {TM's }}$ components on the relation IC-FP. To address this issue, a regression has been carried out exclusively on studies that reported both relation between VAICTM as a whole and FP and relation between the three VAICTM's components and the FP (Kamath, 2008; Jin, 2008a; Jin, 2008b; Jin e Wu , 2008; Zhang et al., 2006; Saengchan, 2008; Najbullah, 2005; Shiu, 2006; Chan,

\footnotetext{
${ }^{48} \mathrm{Q}$-test, in hypothesis of homogeneity between studies, follows a chi-square distribution, with k-1 degrees of freedom, where $\mathrm{k}$ is the number of studies. In order to assess whether there is heterogeneity, the result of the Q-test is compared to a critical chi-square value, calculated to a pre-defined probability level (generally $\alpha=0,05$ ). If the Q-test is lower than the critical chi-square value the hypothesis of homogeneity between studies (null hypothesis, $\mathrm{H}_{0}$ ) is accepted, on the contrary the null hypothesis (our case) is rejected.
} 
2009; Chen et al., 2005), The regression results show that only human capital is a moderating variable on that relation $(p<0.05)$. This result is coherent with the prevailing doctrine, which, in front of empirical evidences, sustains the moderating role of human capital (Bontis et al., 2000; Vali, 2007).

Another important point to highlight is that the researchers use unilateral cause-effect model, without further investigation on possible bilateral relationship between IC and FP, and that often the same measures used to measure IC can be used to measure FP (i.e. EVA, Tobin'Q, Market to book ratio).

The estimation and interpretation of moderating effects is more interesting, even if it represents one of the most problematic issues in contemporary meta-analysis (Steel and Kammeyer-Mueller, 2002). From the analysis it emerges that mainly the economic context, but also industry and FP's measures (productivity) are moderator variables but also that a a great percentage of heterogeneity between studies remain unexplained, since they do not exist enough information in the articles to test other moderator variables.

The article constitutes a pilot study to summarize the studies on the relation of IC and FP through the statistical instrument of meta-analysis. It is an exploratory work that take a risky option embracing an innovative methodological approach. As in any type of empirical research, this study is subject to the limitations that caracterize the statistical analysis generally, such as the availability, numerosity and reliability of data, but it has the merit of having shown that it is possible to draw summarizing conclusions even from numerous and conflicting studies and that cumulative knowledge is possible in business sciences (Hunter and Schmidt, 1996); moreover the discussions presented can constitute hints and investigations for future theoretical and empirical research.

\section{Appendix: Steps and results of the random-effects MA}

\section{Mean effect size}

The application of the random-effects meta-analysis (Hedges and Vevea, 1998) required the following mathematical steps:

1) to convert the various statistical measures, such as $t$ to $r$ according to conversion

formula of Lipsey and Wilson (2001):

$$
r_{i}=\sqrt{\frac{t^{2}}{t^{2}+d f}}
$$

$r_{i}$ is the effect size of study $i$ and $d f$ are the degrees of freedom.

2) to transform the $r s$ into Fisher's $\mathrm{Z}_{\mathrm{r}}$ in order to standardize $r$, that is to made normal its distribution, with the following formula:

$$
Z_{r_{i}}=\frac{1}{2} \ln \left(\frac{1+r_{i}}{1-r_{i}}\right)
$$

2) to calculate the random-effects average effect size. The transformed effect sizes are used to calculate an average in which each effect size is weighted by the inverse variance, that incorporates both within-study and between-study variance (in a fixed-effect model the weight incorporates only the within-study variance):

$$
\bar{Z}_{r}^{*}=\frac{\sum_{i=1}^{k} w_{i}^{*} Z_{r_{i}}}{\sum_{i=1}^{k} w_{i}} \text { where } w^{*}{ }_{i}=\frac{1}{v_{i}}+\frac{1}{\tau^{2}} \quad \therefore w^{*}{ }_{i}=\left(\frac{1}{w_{i}}+\tau^{2}\right)^{-1}
$$

The first component of $w_{i}^{*}$ is the inverse within-study variance, which, for $Z_{r i}$ is equal to $1 /\left(n_{i}-3\right)$ (Hedges and Olkin, 1985, p. 271), therefore the weight $\left(w_{i}\right)$ is the inverse of this, namely the sample size, $n_{i}$, minus three $\left(w_{i}=n_{i}-3\right)$. The second component is the inverse -between study variance. The between study variance is denoted by $\tau^{2}$ and its calculation is based on $Q, k$ (number of studies in MA) and a constant, $c$, such that: 


$$
\tau^{2}=\frac{Q-(k-1)}{c} ; Q=\sum_{=1}^{k}\left(w_{i}\right)\left(Z_{r_{i}}-\bar{Z}_{r}\right)^{2} ; c=\sum_{=1}^{k}\left(w_{i}\right)-\frac{\sum_{i=1}^{k}\left(w_{i}\right)^{2}}{\sum_{=1}^{k}\left(w_{i}\right)}
$$

The $\bar{Z}_{r}^{*}$ has to been converted in $r$ metric with the equation:

$$
r_{i}=\frac{e^{\left(2 Z_{i}\right)}-1}{e^{\left(2 Z_{i}\right)}+1}
$$

3) to estimate the precision of this true effect using confidence intervals, calculated using the standard error (SE) of the mean effect size. The confidence interval around the true effect is calculated in the usual way by multiplying the standard error by the two-tailed critical value of the normal distribution (which is 1.96 for the most commonly used $95 \%$ confidence interval. The upper and lower bounds are calculated by taking the average effect size and adding or subtracting its standard error multiplied by 1.96 :

$$
\operatorname{SE}\left(\bar{Z}_{r}{ }^{*}\right)=\sqrt{\frac{1}{\sum_{i=1}^{k} w_{i}{ }^{*}}} \quad \begin{aligned}
& 95 \% C I_{\text {Upper }}=\bar{Z}_{r}{ }^{*}+1,96 S E\left(\bar{Z}_{r}{ }^{*}\right) \\
& 95 \% C I_{\text {Lower }}=\bar{Z}_{r}{ }^{*}-1,96 S E\left(\bar{Z}_{r}{ }^{*}\right)
\end{aligned}
$$

These values are again transformed back to the $r$ metric.

To test for significance, the following formula from Lipsey and Wilson (2001) has been used. The Lipsey and Wilson's formula assesses significance based upon the Z-value tested at 0.05 significance level:

$$
z=\frac{\left|\overline{Z_{r}^{*}}\right|}{S E_{\overline{Z_{r}^{*}}}}
$$

\section{Moderator analysis}

The highly significant test of homogeneity of effect size for both MAs (respectively $\mathrm{Q}=$, $\mathrm{p}<.001$ and $\mathrm{Q}=$ ) and of $\mathrm{I}^{2}$ (respectively 99,5\% and 99,7\%), where $I^{2}=\frac{Q-d f}{Q}$, suggest considerable variation in effect sizes overall.

In oder to verify ou results and because of the nested nature of the data, a multilevel regression MA has been carried out. The first step in the multilevel model meta-analysis is to estimate the intercept-only model. Multilevel models in meta-analysis stipulate two equations: an outcome level component (level 1) and a study-level component (level 2):

Level 1 equation $Z_{i J}=\beta_{0 j}+e_{i j}$

Level 2 equation $\beta_{0_{j}}=y_{0}+u_{0 j}$

The error term at first level $(e)$ and at second level $(u)$ are assumed independent.

In the level 1 equation, $Z_{i J}$ refers to the Fisher Z-transformed values from relation $\mathrm{i}$ in the study $\mathrm{j}, \beta_{0 j}$ refers to the intercept (average effect size for an average outcome), and $e_{i j}$ refers to the random error (residual) at level 1 . In the level 2 equation, $y_{0}$ represents the regression coefficient and $u_{0 j}$ is the level 2 random error. The level 1 model is the same as the random effects model (Hox, 2002), as it incorporates both the outcome-level and the study-level components. All analyses were conducted using MLwiN programme. The results of the intercept-only model in the multilevel MA are the following:

$$
\begin{aligned}
& z_{i j}=\beta_{0 j}+e_{i j} \\
& \beta_{0 j}=0,293(0,071)+u_{0 j} \\
& u_{o j} \sim N\left(0, \sigma_{u o}^{2}\right) \quad \sigma_{u 0}^{2}=0.045(0.030)
\end{aligned}
$$


$e_{i j} \sim N\left(0, \sigma_{e}^{2}\right) \sigma_{e}^{2}=0.183(0.024)$

$-2 * \log$ likelihood $=163.226(131$ of 131 cases in use)

The variances at residual error at level 1 and level 2 have been used to calculate the intraclass correlation, that explains the proportion of the total variance which is between level-2 units. It is between 0 and 1; the higher its, the larger is variance at the higher level. The intra-class coefficient is equal to $19 \%$.

Intra-class coefficient $\frac{\sigma^{2}{ }_{u o}}{\sigma_{u o}^{2}+\sigma_{e}^{2}}=0.19$

The unexplained heterogeneity requires that the model has to be expanded to include predictor variables; in the hypothesis that all moderators are at effect size level:

Level 1 equation $Z_{i J}=\beta_{0 j}+X_{1} \beta_{1} e_{i j}+X_{2} \beta_{2} e_{i j}+\ldots+X_{s} \beta_{s}+e_{i_{j}}$

Level 2 equation $\beta_{0_{j}}=y_{0}+u_{0_{j}}$

Where $Z_{i J}$ is the mean standardized effect size, $\beta_{1} \ldots \beta_{S}$ are the regression coefficients, supposed to be fixed (i.e. the same effect for all cases), X1 ...Xs are the moderator variables, $u_{0 j}$ is the systematic variability in study $j$ not captured by the $s$ predictors, and $e_{j}$ is the sampling error for the level 1 equation. In order to apply a random effects model, standardized effect sizes have been weighted with inverse variance weights, $\mathrm{w}^{*}$, that incorporates both within-study and between-study variance in combination with constraining the lowest level (outcome level) variance to be one (Hox, 2002). The moderators were codified in term of dichotomic variables (dummies). The results of the random effects (RIGLS) models using inverse variance weights are the following

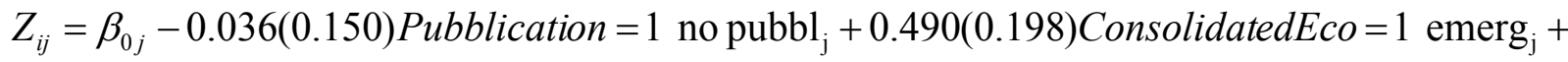
$+0.322(0.165)$ Services $=1$ other $_{\mathrm{ij}}+0.009(0.071)$ Vaic $=1$ other $_{\mathrm{ij}}+0.099(0.130)$ profitability $=1_{i j}+$ $-0.186(0.164)$ sustainability $=1_{j}+0.283(0.152)$ productivity $_{i j}+e_{i j}$

$\beta_{0 j}=-0.147(0.165)+u_{0 j}$

$u_{o j} \sim N\left(0, \sigma_{u o}^{2}\right) \sigma_{u 0}^{2}=0.057(0.028)$

$e_{i j} \sim N\left(0, \sigma_{e}^{2}\right) \quad \sigma_{e}^{2}=1.000(0.000)$

$-2 * \log$ likelihood $=270.283$ (131 of 131 cases in use)

From the analysis, the economic contest, the industry and the use of firm's performance in term of productivity are moderators of the relation, since the ratio between the regression coefficient and the standard error (the number in brackets) is bigger than 1.96.

\section{References}

* Denotes studies that were canvassed for meta-analysis

1. Acedo, F.J., Barroso, C. and Galan, J.L. (2006) The resource-based theory: dissemination and main trends, Strategic Management Journal, 27, pp. 621-636.

2. Ahmit, R. and Schoemaker, P. (1993) Strategic assets and organizational rents, Strategic Management Journal, 4, pp. 33-47.

3. Amir, E. and Lev, B. (1996) Value relevance of non-financial information: the wireless communications industry, Journal of Accounting and Economics, pp. 3-30.

4. *Appuhami, B.A.R. (2007) The impact of Intellectual Capital on investors' capital gain on shares: an empirical investigation in Thai banking, finance and insurance sector, Journal of Internet Banking and Commerce, 12(1), pp. 1-14.

5. Bailar, J. C. (1997) The promise and problems of meta-analysis, New English Journal of Medicine, 337, pp. 559-561.

6. Barney, J.B. (1991) Firm resources sustained competitive advantage, Journal of Management 17(1), pp. 99-120. 
7. Bijmolt, T.H.A. and Pieters, R. G. M. (2001) Meta-analysis in marketing when studies contain multiple measurements, Marketing Letters, 12(2), pp. 157-169

8. Bontis, N. (1996) There is a price on your head: managing intellectual capital strategically, Business Quarterly, Summer, pp. 40-47.

9. Bontis, N. (1998) Intellectual capital: an exploratory study that develops measures and models, Management Decisions, 36(2), pp. 63-76.

10. Bontis, N., Keow, W. and Richardson, S. (2000) Intellectual capital and the nature of business in Malaysia, Journal of Intellectual Capital, 1(1), pp. 85-100.

11. Boreinstein, M., Hedges, L. V., Higgins, J. P. T. and Rothstein, H. R. (2009) Introduction to meta-analysis (Wiley: UK).

12. Bourne, M., Mills, J., Wilcox, M., Neely, A. and Platts, K. (2000) Designing, implementing and updating performance measurement systems, International Journal of Operation \& Production Management 17, pp. 754-771.

13. Brewin, C.R., Kleiner, J.S., Vasterling, J.J. and Field, A. (2007) Memory for emotionally neutral information in posttraumatic stress disorder: a meta-analytic investigation, Journal of Abnormal Psychology, 116(3), pp. 448-463.

14. Carlucci, D., Marr, B. and Schiuma, G. (2004) The knowledge value chain: how intellectual capital impacts on business performance, International Journal of Technology Management, 27(6/7), pp. 575-587.

15. *Cazavan-Jeny, A. (2003) Value-relevance of expensed and capitalized intangiblesEmpirical evidence from France, Working Papers n. DR03022 ESSEC Research Center, ESSEC Business School.

16. *Chan, K. H. (2009) Impact of intellectual capital on organizational performance. An empirical study of companies in the Hang Seng Index, The Learning Organization, 16(1), pp. 4-39.

17. *Chen, M., Cheng, S. and Hwang, Y. (2005) An empirical investigation of the relationship between intellectual capital and firms' market value and financial performance, Journal of Intellectual Capital, 6(2), pp. 159-176.

18. Conner, K. R. and Prahalad, C. K. (1996) A resource-based theory of the firm: knowledge versus opportunism, Organization Science, 7, pp. 477-501.

19. Datta Deepak, K., Pinches, G. E. and Narayanan, V. K. (1992) Factors influencing wealth creation from mergers and acquisitions: A meta-analysis, Strategic Management Journal, 13, pp. 67-84.

20. Derfuss K. (2009) The relationship of budgetary participation and reliance on accounting performance measures with individual-level consequent variables: a meta-analysis, European Accounting Review, 18(2), pp. 1-37.

21. Dyer, J. H. (1996) Specialized supplier network as a source of competitive adavantage: evidence from auto industry, Strategic Management Journal, 17(4), pp. 271-291.

22. Edvinsson, L. and Malone, M. S. (1997) Intellectual capital - realising your company's true value by finding its hidden brainpower (New York: Harper Business Publisher).

23. Field, A. P. (2005) Is the meta-analysis of correlation coefficients accurate when population correlations vary?, Psychological methods, 10(44), pp. 444-467.

24. Field, A. P. (1999) A Bluffer's guide to meta-analysis, Newsletter of the Math, Stat and Comp Section of the British Psychological Society, 7(1), pp. 16-25.

25. Field, A. P. (2003a) The problems in using fixed-effects models of meta-analysis on realworld data, Understanding Statistics, 2(2), pp. 105-124.

26. Field, A. P. (2003b) Can meta-analysis be trusted?, The Psychologist, 16, pp. 640-645.

27. *Firer, S. and Stainbank L. (2003) Testing the relationship between intellectual capital and a company performance: evidence from South Africa, Meditari Accountancy Research, 11, pp. 25-44.

28. Florax, R. J. G. M., De Groot, H. L. F. and De Mooij, R. A. (2002) Meta-analysis: a tool for upgrading inputs of macroeconomic policy models, SSRN paper. 
29. Galbreath, J. (2005) Which resource matter the most to firm success? An exploratory study of the resource-based theory, Technovation, 25, pp. 979-987.

30. Galbreath, J. and Galvin, P. (2008) Firm factors, industry structure and performance variation: new empirical evidence to a classic debate, Journal of Business Research, 61, pp. 109-117.

31. Garcia-Meca, E. and Sanchez-Ballesta, J. P. (2007) A meta-analytic vision of the effect of ownership structure on firm performance, Corporate Governance: An International Review, 15(5), pp. 879-893.

32. Glass, G. (1976) Primary, secondary and meta-analysis of research, Educational Researcher, 5, pp. 3-8.

33. Goldstein, H., Yang, M., Omar, R., Turner, R. and Thompson, S. (2000) Meta-analysis using multilevel models with an application to the study of class size effects, Applied Statistics, 49, pp. 399-412.

34. Gooding, R. Z. and Wagner J. A. (1985) A meta-analytic review of the relationship between size and performance: the productivity and efficiency of organizations and their subunits. Administrative Science Quarterly, 30, pp. 462-481.

35. Grant, R. M. (1996) Toward a knowledge based theory of the firm, Strategic Management Journal, 17, pp. 109-122.

36. Hall, R. (1992) The strategic analysis of intangible resources, Strategic Management Journal, 13, pp. 135-144.

37. Hedges, L. V. and Vevea, J. L. (1998) Fixed and random effects models in meta-analysis, Psychological methods, 6(3), pp. 203-217.

38. Hedges, L. V. and Olkin I. (1980) Vote counting methods in research synthesis, Psychological Bulletin, 88, pp. 359-369.

39. Hedges, L. V. and Olkin I. (1985) Statistical methods for meta-analysis. (Orlando, FL: Academic Press).

40. Higgins, J. P. T. and Thompson S. G. (2002) How should meta-.regression analyses be undertaken and interpreted?, Statistics in Medicine, 21, pp. 1559-1573.

41. HLEG (Higher Level Experts Group) (2003) Study on the Measurement of intangible assets and associated reporting practices, Brussels, "Enterprise" Directorate General of the European Commission, April.

42. Hofmann, D.A. and Gavin M.B. (1998) Centering decisions in hierarchical linear model: implications for research in organizations, Journal of Management, 24 (5), pp. 623-641.

43. Hoopes, D. G., Madsen T. L. and Walker G. (2003) Guest editor's introduction to the special issue: why is there a resource based view? Toward a theory of competitive advantage, Strategic Manager Journal, 24, pp. 889-902.

44. Hoox, J. J. (2002) Multilevel Analysis: Techniques and application (Mahwah: Lawrence Erlbaum).

45. Huang, C. J. and Liu, C.J. (2005) Exploration for the relationship between innovation, IT and performance, Journal of Intellectual Capital, 6(2), pp. 237-252.

46. Huedo-Medina, T. N., Sánchez-Meca, J., Marín-Martínez, F. and Botella, J. (2006) Assessing heterogeneity in meta-analysis: Q statistic or $\mathrm{I}^{2}$ index?, Psychological Methods, 11, pp. 193-206.

47. Hunt, M. (1997) How science takes stock: The story of meta-analysis. (New York: Russell Sage Foundation).

48. Hunter, L., Webster, E. and Wyatt, A. (2005) Measuring Intangible capital: a review of current practice, Research Institute of Australia, paper n. 16/04.

49. Hunter, J. E. and Schmidt, F. L. (2004) Methods of meta-analysis: correcting errors and bias in research findings ( $2^{\text {nd }}$ Edn.), (Newbury Park: Sage).

50. IFAC (International Federation of Accountants) (1998), The measurement and management of intellectual capital, New York. 
51. *Iswati, S. and Anshori, M. (2007) The influence of Intellectual Capital to financial performance at Insurance companies in Jakarta Stock Exchange, Proceedings of the $13^{\text {th }}$ Asian Pacific Management Conference, Melbourne, Australia, pp. 1393-1399.

52. *Jin, S. (2008a), An empirical investigation of the relationship between intellectual capital and firms' development ability, paper presented to the 15th International Conference on Management Science \& Engineering, USA, September.

53. *Jin, S. (2008b), The relationship between intellectual capital and high-tech firms' development ability: evidence from high-tech listed companies in China, paper presented to the International Conference on Information Management, Innovation Management and Industrial Engineering.

54. *Jin, S. and Wu, Y. (2008) The contribution of Intellectual Capital to firm's sustainability growth ability: an empirical investigation based on listed companies in China, paper presented to the International Conference on Information Management, Innovation Management and Industrial Engineering.

55. *Juma, N. and Payne, G. T. (2004) Intellectual Capital and performance of new venture high-tech firms, International Journal of Innovation and Management, 8(3), pp. 297-318.

56. *Kamath, G. B. (2008) Intellectual Capital and corporate performance in Indian pharmaceutical industry, Journal of Intellectual Capital, 9(4), pp. 684-784.

57. Kaplan, R. S. and Norton, D. P. (2004) Strategy maps: converting intangible assets into tangible outcomes (Boston, MA: Harvard Business School Press).

58. Kaufmann, L. and Schneider, Y. (2004) Intangibles: a synthesis of current research, Journal of Intellectual Capital, 5(3), pp. 366-388.

59. *Kujansivu, P. and Lönnqvist, A. (2007) How do investments in intellectual capital create profits?, International Journal of Learning and Intellectual Capital, 4(3), pp. 256-275.

60. La Rocca, M. (2008) Corporate Governance, struttura finanziaria e valore (Corporate governance, financial structure and value) (Milan: Egea).

61. Lev, B. (2001) Intangibles: management, measurement and reporting. (Washington DC: Brookings Institute Press).

62. Lev, B. and Zambon, S. (2003) Intangibles and intellectual capital: an introduction to a special issue, European Accounting Review, 12(4), pp. 597-603.

63. Lindsay, R. (1994) Publication system biases associated with the statistical testing paradigm, Contemporary Accounting Research, 11(1), pp. 33-57.

64. Lipsey, M. W. and Wilson, D. B. (2001), Practical meta-analysis. (Thousand Oaks, CA: Sage).

65. Luthy, D. H. (1998) Intellectual capital and its measurement, available at: htttp://www3.bus.osaka-cu.ac.jp/apira98/archives/htmls/25.htm.

66. Meritum (2002) Guidelines for Managing and Reporting on Intangibles, TSER Programme, Madrid.

67. *Najibullah, S. (2005) An empirical investigation of the relationship between intellectual capital and firm's market value and financial performance in context of commercial banks of Bangladesh, Ph.D. Dissertation, Schol of Business Independent University, Bangladesh.

68. Neely, A. D., Mills J. F., Gregory M. J. and Platts K. W. (1995) Performance measurement system design - a literature review and research agenda, International Journal of Operation and Production Management, 5(4).

69. Nonaka, I. and Takeuchi, H. (1995) The Knowledge-creating company. (New York: Oxford University Press).

70. OECD (1999) Guidelines and instructions for OECD Symposium, paper presented at International Symposium Measuring Reporting Intellectual Capital: Experiences, Issues and Prospects, OECD, Amsterdam, June.

71. O’Mara A.J., Marsh H.W., Craven R.G. (2005) Meta-analytic methods in educational research: issues and their solutions, paper presented at the 2005 AARE (Association for Active Educational research) conference, Paramatta, Australia. 
72. Orlitzky, M., Schmidt, F. L. and Rynes S.L. (2003) Corporate Social and Financial Performance: A Meta-Analysis, Organizational Studies, 24(3), pp. 403-441.

73. Peteraf, M. (1993) The cornerstones of competitive advantage: a resource-based view, Strategic Management Journal, 14(3), pp. 179-192.

74. Petty, P. and Guthrie J. (2000) Intellectual capital literacy review: measurement, reporting and management, Journal of Intellectual Capital, 1(2), pp. 155-175.

75. Pomeroy, B. and Thornton, D. B. (2008) Meta-analysis and the accounting literature: the case of audit committee independence and financial reporting quality, European Accounting Review, 17(2), pp. 305-330.

76. Porter, M. E. (1980) Competitive Strategy: Techniques for Analyzing a Business, Industry and Competitors (New York: The Free Press).

77. Prahalad, C. K. and Hamel, G. (1990) The core competence of the corporation, Harvard Business Review 66(3), pp. 79-91.

78. PRISM report (2003) European Commission Information Society Technologies Programme available at http://www.eu.intangibles.net.

79. Pulic, A. (1998) Measuring the performance of intellectual potential in Knowledge economy, available at http://www.measuring-ip.at/Opapers/Pulic/Vaictxt.vaictxt.html

80. *Pulic, A. (2000) MVA and VAIC ${ }^{\text {TM }}$ Analysis on randomly selected companies from FTSE 250, available at: www.vaic-on.net, pp. 1-41.

81. Pulic, A. (2004) Intellectual capital- does it creates or destroy value?, Measuring Business Excellence, 8(1), pp.62-68.

82. Reed, K. K., Lubatkin, M. and Srinivasan, N. (2006) Proposing and testing an Intellectual capital-based view of the firm, Journal of Management Studies, 43(4), pp. 868-893.

83. *Richieri, F. L., Cruz Basso, L. F. and De Leiva Martin, D. (2008) Intellectual Capital and the creation of value in Brazilian Companies, SSRN, pp. 1-22.

84. Rosenthal, R. (1984) Meta-analytic procedures for social research (Beverly Hills: Sage).

85. Rosenthal, R. (1995) Writing meta-analytic reviews, Psychological Bulletin 118, pp. 183192.

86. Rosenthal, R. and Di Matteo M. R. (2001) Meta-analysis: recent developments in quantitative methods for literature reviews, Annual Review of Psychology, 52, pp. 59-82.

87. Rubino, F. (2004) La creazione di valore come fattore critico per il conseguimento di un vantaggio competitivo sostenibile (The value creation as critical factor for the achievement of a sustainable competitive advantage) (University of Calabria: CEL).

88. *Sangchean, S. (2008) The role of intellectual capital in creating value in the banking industry, paper.

89. Serenko, A. and Bontis, N. (2004) Meta-review of knowledge management and intellectual capital literature: citation impact and research productivity rankings, Knowledge and process management, 11(3), pp. 185-198.

90. Sharpe, D. (1997) Of apples and oranges, file drawers and garbage: why validity issues in meta-analysis will not go away, Clinical Psychological Review 17, pp. 881-901.

91. *Shiu, H. (2006) The application of Value Added Intellectual Coefficient to measure corporate performance: evidence from technological firms, International Journal of Management, 23(2), pp. 356-365.

92. Stanley, T. (2001) Wheat from chaff: meta-analysis as quantitative literature, Journal of Economic Perspectives, 15, pp. 131-150.

93. Stanley, T. and Jarrel, S. B. (1989) Metaregression Analysis: a quantitative method of literature survey, Journal of Economic Surveys, 19(3), pp. 299-308.

94. Stewart, T. A. (1997) Intellectual capital: the new wealth of organization. (New York: Doubleday/Currency).

95. Sullivan, P. (2000) Value driven Intellectual capital: how to convert intangible corporate assets into market value (New York: John Wiley \& Sons). 
96. Suri, H. (2000) A critique of contemporary methods of research synthesis, Post-script, 1.1, pp. 49-55

97. Sveiby, K. E. (1997) The new organizational wealth - managing and measuring knowledge based assets, (San Francisco: Beret-Koehler).

98. Sveiby, K. E. (2001a) Methods for Measuring Intangible Assets available on www.sveiby.com (latest update April 2007, accessed in March 2009).

99. Sveiby, K. E. (2001b) A knowledge based theory of the firm to guide in strategy formulation, Journal of Intellectual capital, 2(4), pp. 344-358.

100. *Tan, H. P., Plowman, D. and Hancock, P. (2008a) Intellectual capital and financial returns of companies, Journal of Intellectual Capital, 8(1), pp. 76-95.

101. Tan, H. P., Plowman, D., Hancock, P. (2008b) The evolving research on intellectual capital, Journal of Intellectual Capital, 9(4), pp. 585-608.

102. Teece, D. J., Pisano, G. and Shuen, A. (1997) Dynamic capabilities and strategic management, Strategic Management Journal 18(7), pp. 509-533.

103. Tseng, C. and Goo, Y. (2005) Intellectual capital and corporate value in an emerging economy: empirical study of Taiwanese manufacturers, R\&D Management, 35(2), pp. 187201.

104. Van Den Noortgate, W. and Onghena, P. (2003) Multilevel meta-analysis: a comparison with traditional meta-analytic procedures, Educational and Psychological Measurement, 63, pp. 765-790.

105. Väisänen, J., Kujansivu, P. and Lönnqvist, A. (2007) Effects of intellectual capital investments on productivity and profitability, International Journal of Learning and Intellectual Capital, 4(4), pp. 377-391.

106. *Vali, (2007) Determining causal relationship between IC drivers \& performance- a structural equation modeling approach, submitted to the $3^{\text {rd }}$ Workshop on Visualising, Measuring and Managing Intangibles and Intellectual Capital, Ferrara.

107. Veltri, S. (2008) Empirical evidence of relationships between Intellectual Capital performance and firm value, Economia Aziendale Online, 2/08.

108. *Villalonga, (2004) Intangible resources, Tobin's Q, and sustainability of performance differences, Journal of Economic Behavior and Organization, 54, pp. 205-230.

109. Wernerfelt, B. (1984) A resource-based view of the firm, Strategic Management Journal, 5(2), pp. 171-180.

110. Zambon, S. (2003) New approaches to the measurement and reporting of intangibles, chapter 5 in HLEG, Study on the Measurement of intangible assets and associated reporting practices, Brussels, "Enterprise" Directorate General of the European Commission, April.

111. *Zhang, J., Zhu, N. and Kong, Y. (2006) Study on intellectual capital and enterprise performance. Empirical evidences from the Chinese Securities Market, Journal of Modern Accounting and Auditing, 2(10), pp. 35-39.

112. Zingales, L. (2000) In research of new foundations, working paper 7706, Cambridge, Mass. 